\title{
POPULIST EFFECT IN USE OF ART TO MANIPULATE FINANCIAL STATEMENT IN MFIS
}

\author{
Achmad Ridwan Sholeh, Iwan Triyuwono, Muhammad Achsin \\ Fakultas Ekonomi dan Bisnis, Universitas Brawijaya, \\ Email: Achmad.ridwan0901@gmail.com
}

\begin{abstract}
ABSTRAK
Praktik creative accounting atau manipulasi laporan keuangan merupakan jalan pintas bagi setiap entitas demi mencapai tujuan-tujuan tertentu. Penelitian ini bertujuan mengungkap motif-motif yang tersaji atas praktik manipulasi laporan keuangan pada LKM (Lembaga Keswadayaan Masyarakat) Karapan Sapi. Berdasarkan hasil penelitian di lapangan didapat bahwa LKM Karapan Sapi melakukan praktik manipulasi pada pengelola keuangan (UPK). UPK melakukan praktik manipulasi dengan cara rescheduling pada akun pinjaman agar biaya resiko pinjaman menjadi rendah pada laporan laba rugi. Hal ini menyebabkan penekanan pada sisi biaya, sehingga memperbesar pendapatan. Berdasarkan penggalian motif atas praktik yang dilakukan oleh UPK LKM Karapan Sapi, maka didapatkan hasil bahwa pengelola keuangan ingin menyelamatkan alokasi simpan pinjam yang ada pada dana bantuan pemerintah dibawah program PNPM. Terdapat indikasi bahwa pengurus berusaha meningkatkan kepercayaan masyarakat terhadap mereka
\end{abstract}

\section{Kata kunci: Manipulasi, Laporan Keuangan, LKM}

\begin{abstract}
Creative accounting practices are shortcuts for every entity in order to achieves some special purposes. This study aimed to uncover the motives of creative accounting practices in MFIs (Self-Supporting Community Organization) Karapan Sapi. This study uses interpretive paradigm with a case study approach in order to know well the creative accounting practices that have taken place and ongoing. Based on the results of field research found that MFI Karapan Sapi do the creative accounting at UPK (Financial Management Unit). UPK is one of three units in the body of the MFI Karapan Sapi that focus in saving and loans. UPK do the creative accounting by rescheduling excessively the loan of KSM (group of creditor) in order to lower the cost of loss reserve account in income statement. Based on the field information, the motive of creative accounting practices by UPK MFI Karapan Sapi, it showed that the UPK would like to save the allocation of loan that exist in government funding under the PNPM program and there is an indication that UPK want to pull up the image of MFI management.
\end{abstract}

Keywords: Manipulation, Financial Statement, MFIs 


\section{A. INTRODUCTION}

"If you can't make it good, make it look good" the phrase proposed by Bill Gates is very suitable in conditioning the current trend of financial statements. The financial statements are a reflection of an entity. A good financial statement will also provide a good rating from the user's point of view. Based on the reflection, there are many entities that "polish" their financial statements to look good. Degradation of accounting values is one of the adverse effects of the financial statement manipulation activity. The financial statements are biased so that it will have an effect on decision making. Entities attempt to boost the financial statements for a particular interest. Figures on financial statements that are manipulative certainly do not describe the existing performance. This tricky technique is like an enchanting cover covering unpredictable contents from the outside.

The current accounting developments provide rooms to legitimize the game in the financial statements. Reporting and recognition methods in accounting are often used to black out the existing information. Amat, Blake, and Dowds (1999) argue that manipulating numbers is a process in which the accountants use their knowledge of accounting rules to manipulate numbers reported in financial statements. "Hole" in the financial statements is fixed so that the information presented is in accordance with the expectations of the reader. This requires an accountant who proficient with accounting records so as to know the gaps that can be used. Various reasons for the implementation of financial statements manipulation are pressure, opportunity, and rationalization (Well, 2005: 334).

Financial statements manipulation can cause various problems. The interpretation of common readers on financial statements is limited to the surface without knowing anything behind it. Some internal issues over performance are neatly covered by management. Zuca and Ioanas (2012) argue that management's choice of accounting policies creates the possibility to provide solutions to achieve goals well. Schilt (2002: 235) states about the issue of financial reporting is as follows

"The first half of twentieth century witnessed numerous instances of financial shenanigans in corporate annual reports, leading to grossly overvalued stock prices and contributing to the collapse of the stock market between 1929 and 1932. One of them for example, the price of International Power, Inc's stock dropped 78 points in a single day when it was reported that had company had 'cooked the books."

The history of this financial statement is the learning for users of financial information. Financial statements can be a double-edged knife. Not having a caution for users can be a disaster for themselves. Characteristics of relevant and reliable financial statements (PSAK No. 1) are being abandoned. These modern, financial statements began to turn into a tool for management to legitimate interests. Interests that can harm users are also made for personal gain.

Manipulation of financial statements generally gives an effect to reduce friction between principal and agent according to agency theory. Management tries to present good financial statements by increasing wealth reports for owners and creditors. The information presented in the financial statements is expected to be accepted by the reader pleasurably. For example, by increasing profits, they cheat around it (Krisna and Paul, 2003). For this incident, many parties are greatly disadvantaged. Tricky actions make a win-win solution for management. The benefits gained are the effect of the application of manipulative action. This study will discuss the so-called adverse effects of the results of manipulation of financial statements numbers.

Study site is PNPM Mandiri-Urban which is a continuation of the P2KP program (Urban Poverty Reduction Program) which was implemented since 1999 as an effort by the Indonesian government to build community independence and assist local governments in tackling poverty in a sustainable manner (Ministry of Public Works, 2012: 6). PNPM is funded by the government through foreign loans from the World Bank. This program is continuing in the administration of President Jokowi in 2015-2020. The focus of PNPM is community empowerment, empowering community capabilities in building and assisting the surrounding. PNPM provides many benefits for the community both beneficiary and nonbeneficiaries. 
Transparency and accountability are prioritized in the PNPM program as a mandatory requirement for accountability of aid funds. Sustainability of fund disbursement to MFIs depends on performance report. It is administrative obligations for MFIs to create organizations that reflect good corporate governance. Evidence of the implementation of transparency and accountability obligations is that each MFI is required to keep a book of financial statements. Monitoring the running of funds in the PNPM program is very strict. Regular audits are required by the central government (BPKP) to independent parties through the public accounting firm (KAP). This is done so that the program funds are in accordance with the allocation.

The many basic problems of PNPM are the misuse of government assistance funds. During the period of approximately 15 years, there were many problems with the program. The government acknowledges that the funding is highly vulnerable to corruption. Total corruption reached Rp 200 billion since 2007 according to Deputy Coordinating Minister for People's Welfare for Poverty Reduction, Sujana Royat at the National Meeting of PNPM Mandiri 2012 in Jakarta, December 4, 2012 (www.nasional.tempo.co). A fairly high number if it is used for the development of remote areas.

The number of problems in this study is reviewed based on the financial reporting of the program. Financial reporting reflects the performance of an entity that can be assessed whether it is healthy or not. Study of in-depth financial statements is done to find out what is behind the manipulative numbers underlying fraud. Deception in the financial statements is a form of misuse of financial statement information delivery (Singleton; 2006). This kind of action needs to be reviewed in order to improve government programs in the future. The fundamental difference in the background of fraudulent financial reporting in this paper is that the entity under review is a non-profit oriented entity.

\section{B. THEORETICAL BACKGROUND}

Manipulation of financial statements or better known as creative accounting is a major problem in financial statements. According to Mulford and Comiskey (2002; 3) creative accounting is any and all steps used to play financial numbers, including aggressive choice and application of accounting principles, fraudulent financial reporting, and any steps taken to earnings management or income smoothing. Accounts in financial statements are target exploitation by management. Manipulation of financial statement has many tricky techniques and their effects from the treatment. Levitt (1998) on his speech told us that there are 5 types of financial statement games, big bath charges, creative acquisition accounting, cookie jar reserve, materiality, and revenue recognition. One of the most frequently found tricky techniques is to use accrual basis. Accrual basis is based on purposes of management (Fabio and Giorgio; 2012). This treatment can affect financial reporting and increase its value on the eyes of the stakeholder.

The research of Summers and Sweeney (1998) suggests that profitability make a big impact to financial reports. The advantages and disadvantages of a business entity are very concern for management and stakeholders, managements have responsibility to do a good thing for their companies. The smoothest technique for increasing profitability is using accrual basis. Skousen et al (2009) argue that profitability is not main focus account in manipulation of financial statements. This is in line with Nindya (2017) who argues that profitability is not related to the manipulation of financial statements. Statement from Schilit (2010: 4) about profit growth is not in accordance with the performance of the company on field. Profitability does not always reflect creative accounting actions or manipulation of financial statements.

Motivation of the management in use of creative accounting according to Syed, Syafdar and Yasir (2011) is to meet internal targets, meet external expectations, provide income smoothing, window dressing for an IPO or a loan, and change in management. Manipulation of financial statements largely determines the success of management objectives. Without creativity and modified in making a report, the performance related to financial statements cannot accelerated to be good performance in a case. Mulford and Comiskey $(2002 ; 4)$ have an opinion about motivation of the management with the allocation of share prices, borrowing costs, bonus plans and political costs. Both of them are similar in explaining the motivation of financial statement manipulation. 
Some motives based on perspectives from internal and external pressures. Both of them make a big problems of transparency and reliability in financial statements. According to Moses (1997), the company do tricky actions on the financial statements because of the compulsion of obligations that must be fulfilled by the management from the external. Based on Tiffani and Marfuah's (2015) research, the leverage and the manipulative actions of financial statements are not separated. Leverage that arises in an entity is very vulnerable to influence manipulative actions. In line with Andini, Mohamad, and Dedik (2017) revealed external pressures had an impact on financial reports that led to manipulation.

\section{RESEARCH METHOD}

This study is a qualitative research with interpretative paradigm. Directly or not, the writer will involve the element of subjectivity in the study. Subjectivity is the soul in interpretative research. Subjectivity will add value to the study (Triyuwono, 2006: 217). Direct involvement in the field has an impact in creating value-rich qualitative research. The approach that used is case study. The case study is used in accordance with the description of the purpose of financial statements manipulation. The approach is based on the actual condition and prioritizes the naturalistic nature, thus representing the situation.

Site in this study is kelurahan (urban village) beneficiaries of PNPM Mandiri-Urban program. The entity of this study is Karapan Sapi MFI (not its real name) of East Java Province. The determination of study site is based on in-depth observation and suitability of information with the study. The informants of the study are daily administrators associated with the recording of financial statements and associated MFI members as a whole.

Method of collecting data in this study uses interview method, field observation, and documentation. Access to these three has been obtained through a pre-research approach. Preresearch approach has been conducted by the writer for a period of 2 years. Socializing with the informants is used so that the information provided implies hidden content (Creswell, 2007: 57). Making financial statements is a content that not everyone knows about. People only read the financial statements without knowing the story behind the making of financial statements.

In testing the obtained data, technique that used is triangulation technique. Checking data from various obtained sources and matched them against each other (Sugiyono, 2010: 273). This is done to get valid and reliable data. Validity and reliability will make the obtained information is in accordance with the reality that occurred on the study site.

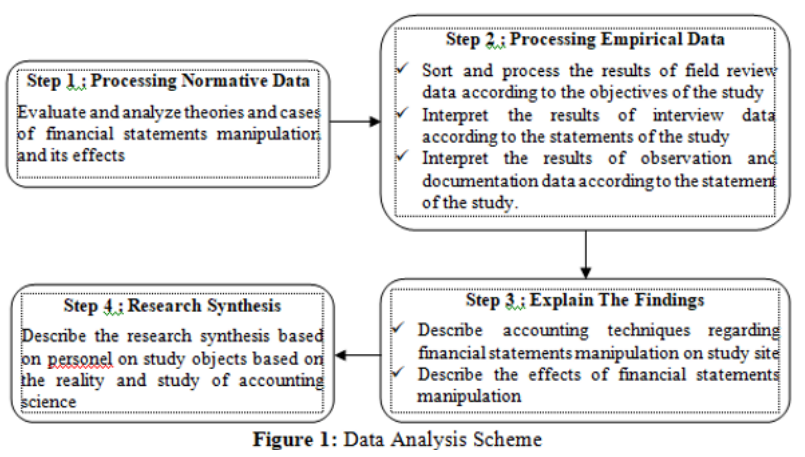

\section{RESULT AND DISCUSSION}

\section{Financial Statement Manipulation Techniques}

There have been many books describing various types of financial statements manipulation techniques. One of the most famous is the Financial Number Games. In Mulford Comiskey's explanation, there manipulation techniques that are still in tolerance domain and some are crashing into existing accounting rules. In this study after going through observation of entities related to manipulative actions of financial statements, the tricky was found. This action has exceeded the regulatory limits set by Operational Standards of the entity as well as the generally accepted Financial Accounting Standards.

The MFI's financial statement is not as complex as the company. Accounts that are presented are simpler to make it easier for common people to understand good bookkeeping workflow. Problems will begin when a bookkeeper/accountant has advanced. A proficient bookkeeper, of course, wants to present the best financial statements. This also applies to the MFI. The management tries to present good financial statements. Sometimes this kind of thing makes accounting difficult so there is no consistency in it (Tingkang Liu; 2017). 
MFI has constraints on accounts receivable which is a major business of MFI. Accounts receivable are assets that should be very productive. Cash flows in this account determine the life or death of MFI entity. Receivables performance in the last period is not smooth. Poor performance has a negative impact on the presentation of the overall financial statements. To correct the problem of presenting financial statements, the bookkeeper uses bookkeeping skills in an effort to improve the financial statements. The bookkeeper uses two techniques in improving accounts receivable. Both can improve the overall financial statements. Explanations of both are presented below.

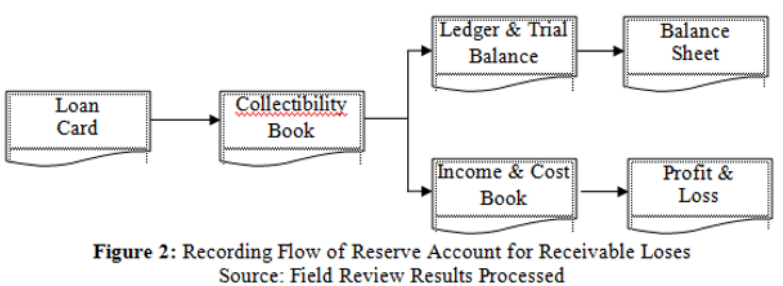

\subsection{Rescheduling}

Karapan Sapi MFI uses the allowance for receivables method in its recording. This method will certainly have a direct impact on profit and loss accounts. Allowance for receivables has been determined in accordance with the MFI's bookkeeping guidelines. Charges are adjusted to the level of delay from installments. Here is a list of allowance of receivables used:

\begin{tabular}{|c|c|c|c|c|}
\hline \multicolumn{5}{|c|}{ Collectibility } \\
\hline Current & $\begin{array}{c}\text { Special } \\
\text { Mention }\end{array}$ & Substandard & Doubtful & Bad \\
\hline Allowance for receivables : The sum of each group is multiplied by the \\
percentage
\end{tabular}

Figure 3: Percentage of Allowance of Receivables Charges Source: Field Review Results Processed

In the tricky realm, MFI tries to charge receivables in the current category with what is called rescheduling. It means KSM loan rescheduling. Rescheduling is done so that the remaining installments will be lighter. The remaining loans are repaid in a longer period and with a smaller nominal value. This practice benefits the borrower and the MFI. The borrower can pay off installments lighter and MFI can report finances better.
With regard to reporting, the loans that have been practiced by Karapan Sapi MFI tend to be misused. The rescheduling treatment was carried out by the bookkeeper so that the troubled KSM loan does not touch the doubtful and bad category collectability. If KSM touches these two categories, then the imposition of the profit and loss is very large. Excessive imposition has a negative impact on the performance of the income statement. At the end of the period, a bad loan will erode profit.

The existence of rescheduling will bring up other income posts. Other income from the rescheduling is a temporary profit hallucination if the receivables are uncollectible. To further refine rescheduling, it is done on the mid-month date to hide the transactions at the end of the reporting period. The financial statements that are informed to the public are only in the form of transaction numbers per month. This raises the impression that the performance so far is still no significant problem.

Rescheduling applies only once to one borrower. If this has been done, then this technique should not be used again. While MFIs through the bookkeeper carried out this action repeatedly to cover loan performance that does not improve. This has violated the existing accounting rules. A small allowance expense and an increase in income from other income increases are deceptive technique. What happens to an MFI is an excessive bookkeeping technical action with the intent of obscuring public information.

\subsection{Writing off Receivable}

Another technique discovered after analyzing the bookkeeping of Karapan Sapi MFI is writing off receivable. This technique is a violation based on the MFI's operational procedures. This is due to the fact that funds scattered in the community are not misused by irresponsible parties. Writing off receivable is not recognizing the receivables as assets of the MFI. It can be considered as an assets theft. Assets loss without written accountability

Writing off receivable is a shortcut to overcoming high level of collectability in financial statements. This practice undermines the capital account that supports the running of the entity. If this practice is carried out periodically, it will be very likely be able to make apocalypse for the MFI itself. This will 
certainly be very detrimental to many people. Funds that must be rotated for mutual benefit will be reduced due to parties who are not responsible for loans.

Writing off receivable can also be done by cutting the value of savings. The rule is unknown. The write off using the borrower's saving can be used as an alternative solution. The reality is that the borrower's savings is always insufficient for the rest of their receivables, leaving a balance of receivables that still settle and must be repaid. Savings of the majority of borrowers is no more than $20 \%$ of their receivables. This is a prerequisite for making loans where the borrower must save at least $10 \%$ of the total loan application.

Under certain conditions, writing off can be done by mutual agreement. This can be done if the borrower dies and does not have a heir. This is also very rare because the majority of borrowers are in the productive age range. According to the management statement, writing off does not often done because the loan application procedure begin to improve. Writing off receivable is done at the beginning of the PNPM program in early 2000. This happened due to lack of understanding of the early period of accounting and other elements that could be categorized as criminal act. The removal of assets without accountability has been greatly minimized so that the MFI does not receive sanction for termination of aid funds.

\section{Effect of Financial Statement Manipulation}

The treatment of recording financial statements conducted by MFI has a chain effect. Effects that arise are personal or group benefits. Such effects are unavoidable for financial statements that show good performance, both in terms of reality and manipulative performance. The effects obtained are a synthesis of the results of the study after going through the interview procedure, continuous observation, and documentation of MFI reports.

The resulting effect means that the financial statements are a reflection of the entity. Good and bad an entity will influence the surroundings. Such influences can be felt directly and not. Some effects of the manipulation of MFI's financial statements are as follows.

\subsection{Community Opinion}

Seeking political benefits can occur. The income statement is a benchmark for the success of the MFI's management. Management are said to be successful in managing savings and loan funds if the report shows a profit. Successful opinions formed in the community provide benefits for them. In this context, each board of the MFI becomes well-known among the community. They have a good image around. This makes it easier for them to lead public voices regarding certain interests.

Aspects of financial statements are part of performance. If the financial statements are good, then the performance of management can be trusted. According to Moses (1997), company carries out creative actions on the financial statements because of the compulsion of obligations that must be fulfilled by the company from the external. Opinions formed from the community can have an effect on the organization and the management in it. This gives a positive value to still be elected as the management in the next period. Mastery of entities that are too dominant and over a long period of time has a high risk of misuse. The will understand the loopholes that can be used for personal gain. Substitution of administrator provides a new atmosphere even though it could worsen the performance that has been built.

The observation of several MFI administrators on the effect of holding opinions is extraordinary. They have a good reputation in the community so they are known in the region. The majority profits are related to general elections. The reality is that not a few of MFI administrators are members of a party and later become the peoples' representatives in DPR. At the time of the nomination of the legislative council, especially the district/city, members of the MFI already have public voice savings. Good opinions that have been built before can be useful in this condition. Community support will facilitate their steps to occupying the position in their environment or as a respected person needed.

\subsection{Allocation}

Based on the information obtained in the field, it is stated that if the savings and loans have poor performance, they will be stopped. Termination is as compensation for the inability 
of the management in managing funds. Based on information from MFI's bookkeeper, the processing of numbers in the financial statements aims to maintain existing allocation. By making improvements to the financial statements, it is hoped that in the future the allocation will continue. Such things if viewed from the writer's personal perspective, there is a gambling system. The nature of gambling resulted from the regulation of the savings and loans itself. Savings and loans that do not require collateral have a high risk. At the same time, the loan guarantee is only the copy of the latest ID card (KTP). Weak economic customer focus adds to the existing level of risk. If the allocation that tries to be maintained fails, then more funds will not settle. Funds that settle in the community will need extra effort in billing. Conversely, if savings and loans improve, the financial statements will look smooth.

Allocation will strengthen capital on savings and loans. To reduce problems, management will be more selective in choosing savings and loans customers. Credit is a promising business in rotating funds. A smooth installment will create a positive value on cash flow compared to other businesses. People will have an interest in loans if they need something. This is also due to urgent needs and lack of adequate cash. The way taken if they do not have cash is of course with credit. Competing interest will make more value for entities engaged in savings and loans. The mushrooming of financing businesses in various regions is a result of the need for loans. If managed properly, the development of savings and loans in MFI can compete with other microfinance. When MFI's savings and loans are well organized, the size of the entity will develop by itself. Seeing this reality, based on personal observation, the MFI's savings and loans program is further enhanced in the improvement of operational system. Only giving ID card is too risky for the sustainability of the program. Collateral requirements should be applied even though they do not have to be as strict as bank loan. Punishment is applied when the borrower violates the rules.

The information obtained is that MFI's savings and loans reduce the community to owing to moneylender. This moneylender is one of a thousand problems from people who need urgent funds. Based on the information from the people, the loan sharks always appear when there are people who are struggling with funds. If observed, savings and loans certainly have advantages over moneylender or official institutions that have complicated requirements. One percent interest and can be negotiated are its own advantages. Easy requirements make MFI's savings and loans to become very popular. If there is a customer experiencing incompetence in installments to the MFI, it is resolved by deliberation. It is different with the moneylender that the majority of them act violently to confiscate assets. The rise of MFI's savings and loans will slowly fight off the moneylender.

\subsection{Wage}

Based on the AD/ART (Articles of Association/Bylaws) of the MFI, the MFI's savings and loans performance determines the wages of its officer. Profit or loss can affect the decision making and one of them is the determination of wages for savings and loans officer. If the savings and loans performance is good, then the wages for savings and loans officer also increase. Wages for the officers are in the form of rewards for their performance in helping to channel savings and loans funds to the people in need. It is possible that the wages determined based on the performance can be manipulated on performance report based on unilateral greed. As Tuanakotta's opinion (2010) that financial deviation is based on one element, namely personal greed.

MFI that are social organizations are certainly not concerned with wages. Savings and loans officer do not question the wages they receive. It is proven by a wage that is only two hundred thousand rupiah per month. Such money in this today is not a reward that can be categorized as commensurate with what they have done. It proves that savings and loans officers are sincere that what is done is an activity to help others. They believe that alleviating the burden of the people in need will get a greater reward from the Almighty than just money in the world.

During getting to know the officer in her daily life, she is a modest person. Jewelry that is seen is only a ring embedded on her finger that probably is just a wedding ring. She never looks fancy and glamorous. Long veil always accompany her daily activities. The people around her also thought like that regarding the savings and loans officer. If material that she is 
pursuing, then of course she does not want to be an MFI's savings and loans officer. The most feasible option is to become a moneylender in which the business field is the same but with far different result.

\section{RESEARCH SYNTHESIS}

The motive above has a difference when viewed in terms of beneficiaries on the practice of modifying financial statements. The different motives can be categorized into personal interests and group interests. Personal interests tend to be personal to someone so that the impact is only enjoyed by one person. In group interests, the impact can be enjoyed jointly in a limited scope. This limited scope is usually the personalities who still have relationship with the involved entity, in this context is MFI.

The practice of manipulating financial statements that occurs is more directed at bonuses. Bonuses are personal motive that are only enjoyed by the involved person who conducts the practice. This does not rule out the possibility that it happens in other places too, especially entities that are profit oriented. With a good income statement, employee bonuses for performance also increase. This is acceptable if the information provided in the financial statements is in accordance with the existing conditions of the reality. The practice of increasing profits provides a shortcut to bonus giving so that there is dishonesty from the person in order to enjoy personal benefits.

The group interest here based on the findings in the field is to save allocations. This interest can only be enjoyed by certain groups. Beneficiaries of this second motive are broad. Certain groups that cannot enjoy are those who are not included in the poor category as PNPM's vision and mission in poverty alleviation. The practice of manipulating financial statements has obscured information from the conditions of MFI's savings and loans. Such problems can be misused so that bad loans that have been fixed in the financial statements are completely uncollectible. This can continue in savings and loans allocations in the following years. Losses can be caused by the donor that is the government. The government advocates by running programs based on good and correct operational procedures in accordance with the provisions.

\subsection{Populist Effects}

Mulford and Comiskey (2002: 4) state that not only the two things that motivated the modification of financial statements. There are several classifications such as bonuses, share price, political cost, and borrowing cost. By looking at the conditions in the field and adopting some literatures on the motives that often occur, the synthesis of this study consists of two groups.

\begin{tabular}{|l|l|}
\hline \multicolumn{1}{|c|}{ Personal Interests } & \multicolumn{1}{c|}{ Group Interests } \\
\hline $\begin{array}{l}\text { 1. Bonus Effect } \\
\text { 2. Populist Effect (Personal) }\end{array}$ & 1. Allocations Effect \\
2. Populist Effect (Group) \\
\hline \multicolumn{2}{|c|}{ Figure 4: Distribution of Effects } \\
Source: Field Review Results Processed
\end{tabular}

Populist effects in MFI are seen as two aspects of interest. Populist effects in MFI can be classified into personal interests and group interests. These populist effects give the other party's view of individuals/groups. The effects increase the value of these individuals/groups so that they are seen as good by the community. By prioritizing the views of other communities on the goodness of individuals/group tends to be able to ease the steps when dealing with other communities. This can increase the self-esteem of the management, in this case of course the management of Karapan Sapi MFI. Based on the information obtained, the ease to blend with the community is implicitly lies in the populist effects of personal and group interests by increasing the dignity of the entity. Increased self-esteem gained in processing financial statements into a better one is called a populist effect.

The populist effect of applying financial statements manipulation is personal. This has been explained in the previous chapter that a good financial statement also affects certain people. In MFI, if there is an administrator who wants to advance in the election of the Regional Representative Council (DPRD) in the regency, then he already has a voice in the community. This is because of his active activities in social organizations that are in contact with social communities. Social closeness makes it easy for people who want to advance in the election as representatives of the people. They have a voice saving from daily social activities without excessively campaigning.

In a populist effect for group, namely the assumption of community over the community 
in which the MFI is responsible for debts and receivables. When MFI experiences its savings and loans problems, other communities will directly or indirectly justify that the community of kelurahan is not trustworthy in terms of debts. This effect provides a good assessment of the dignity of an area regarding debts. Other people do not look down on the people from the village in the matter of the mandate of debts and receivables. In this case, the effect is to improve integrity widely within the scope of one village/kelurahan.

Both of these motives lead to creative treatment of ownership of financial information. They socialize good information from their social performance to the reader of financial statements. The reader of financial statement who has an interest in making decisions based on financial statements information will cause errors, especially if the reader is not a person who is an expert in accounting. As for the person who does not have access to information on an account, he will only look at the surface. The populist effect gives an overview to the general public that the management has performed well in managing the MFI.

\subsection{Cat \& Mouse Accounting}

In a society that holds firmly to local wisdom, manipulating financial statements cannot be justified. Based on the explanation of the motives above, both for personal interests and group interests, one or both of them are always present in every issue that concerns the interests of the community. Taking the opportunity to use the knowledge that is owned is an advantage itself even thought the act of cheating cannot be justified.

The shift in cultural values in the study site tends to show materialistic traits than prioritizing honesty, however, it still cannot be separated from a strong fraternal side to help close relatives and neighbors who are in need. The intention of the MFI to the practice of processing numbers is good, but it is done in the wrong way. This case reminds me of the story of someone on his journey to become a guardian namely Raden Mas Said Sunan or better known as Sunan Kalijaga. The story of Sunan Kalijaga teaches that good intention must be done in a good way too.
Both interests resulting from the manipulation of financial statements namely personal and group interests can only explain the dishonesty that occurred on the study site. Justification that sometimes can be accepted by common sense as something good is sometimes difficult to distinguish by bad action. The trick of processing numbers in financial statements always presents information that is different from the reality. This shows the purpose stated in the previous discussion even though it is done by tricking the financial statements. Speaking of ethics in financial statements information, this synthesis is based on perspectives in Madura culture. It is stated based on the location of the study site. The stereotype that is built from the name of Madura is not very good in the general public. The issue of lending and borrowing is very sensitive for everyone. Some say that lending and borrowing can damage the relationship. The hard character of Madurese makes the existing loan problems even murkier. A family atmosphere that was initially harmonious becomes cracked and could lead to fight that is known as carok. To reduce unwanted things, loans information is hidden and handled with a good approach.

The problematic loans that occur will certainly have an impact on financial statements. Financial statements become unsightly. Bad financial statements will also damage the relationship between management and the community as stakeholders of the program. Based on the previous discussions, the bad loans are not always caused by the borrowers who violate the agreement. Bad loans based on the profession of farm laborers are also caused by the harvest period. In planting period, of course there is no income which causes the report in the worst condition, especially if the harvest fails. This led to a restructuring of the financial statements that can called by cat-mouse. This term is used based on etymology of chasing and hiding. The management tried to pursue the target while covering the lack of performance. To reduce the existing social upheaval, this can be very useful. The information provided is strived as best as possible so that they can be seen as successful in managing the organization.

Cat-mouse also has a purpose if the target as a prey is caught, the problem is gone without a trace. In this context, prey refers to installments that are arrears by outstanding loans 
during the planting period to the farm laborers. The target that caught is the installments of months of arrears paid off during the harvest. This cause the rescheduling financial statements seem to have not experience a decline financial performance. Previous bad loans that occurred are only as dust passed for financial statements.

In the practice of financial reporting conducted by MFI, the cat-mouse can be indicated based on the statements from the chairman of MFI, Mr. RA. He said that a forum meeting, if the MFI can present good financial statements, he feel proud over the others MFIs. It is the same with the statements of Mrs. C regarding meeting with the village head and other internal village heads about the financial statements. It is because financial statements are one of the benchmarks for the management performance. By presenting good financial statements, the management avoids embarrassment because the community is in arrears of loans. To eliminate the assumption of a lot of misuse of funds, this kind of actions needs to be done. Basically, if the majority of borrowers are farm laborer, it is understandable because their income is not like employees.

Financial reporting that is changed in such a way as to bring up numbers that are rated by the users as good. They polish as best they can to make it looks like the reality. Regarding showing information, there are no problems if it is indeed the demands of transparency. Problems arise when there are attempts to hide their weaknesses so that they do not get a disparity in social life. It is a kind of providing a barrier so that the management of MFI is not subjected to public scorn. The cat-mouse context also occurs between the management and stakeholders. The general public will certainly be easy to believe what the management regarding the financial statements. The management has the trust of the surrounding community, so that problems like this can be suppressed. Such cat-mouse accounting is very useful if there is a mismatch such as farmer's income and the existing loan system. This practice also gives a populist effect for the organization's management.

\section{E. CONCLUSIONS AND SUGGETIONS 1. Conclusion}

Financial bookkeeping in MFI is classified as simple. Not many accounts adorn financial statements. If the reader has a formal accounting education background, it is very easy to understand the accounting flow in MFI. The PNPM program is the best concept by government in terms of orderly administration. This provides learning for the community to be orderly administration and understand the concept of simple bookkeeping. The management is responsible for monitoring the quality of information contained in the financial statements and ensuring that their actions aligned with stakeholders (Ayman; 2017).

Savings and loans management in Karapan Sapi MFI has constraint that is the credit installments whose repayments are often late. Business capital loans are often used in consumptive matter. This kind of misuse often causes problems in terms of installments. Bad credit has an impact on financial statements. The income statement according to them shows the management performance. Profit can be interpreted as good performance and vice versa, loss shows poor performance. In order to minimize the impact of opinion of the community, it used to manipulate the financial statement numbers. Processing numbers is an art in accounting and financial reporting. It is in contrast with that social entities are less able to manipulate financial reporting.

Some of the actions that motivate the manipulation of practice financial statements are leading public opinion that the performance of the management is good. It is public opinion in interpreting profits in financial statements. Another motive based on the obtained information is to save the savings and loans allocation. By reporting good financial statements, the savings and loans allocation can continue to be disbursed every period. This can reduce moneylenders that are increasingly mushrooming at the study site.

Rescheduling is the method that used in smoothing the motives. Rescheduling affects accounts receivable in financial statements. Loan risk reserve costs are small, not because they have been improved. Rescheduling practice is a legal way with certain requirements. Rescheduling practice is permitted once and with mutual agreement between management and KSM. Based on the facts in the field, rescheduling has been done without any agreement and exceeded the limit. This kind of depreciation is a very subjective decision (Onojah, Unegbu; 2013). With this practice, the borrower can repay the remaining loan with a smaller installment. This method is a win-win 
solution between the management and borrowers and can also be a time bomb for the organization. Another technique used is the writing off receivables. This method has not been used in the study site for a long time because it is illegal and violates the rules.

\section{Suggestions}

Based on the results of research, manipulation of financial statement in this case based on social organization and government program. This entity is very different with cases of big company like enron. Management of MFIs Karapan Sapi ddo the tricky treatment in financial report by their long experience.

Furthermore the management should make report of their financial accordance to the reality on field. It will honor of fairness in financial statement ethics and not blurring the stakeholders.

\section{F. REFERENCES}

Amat, O., Black, J., and Dowds, J. 1999. The Ethiccs of Creative Accounting. Economic Working Paper

Andini, D., Mohamad, R., and Dedik, N. 2017. Pengaruh Faktor-faktor Fraud Triangle Terhadap Financial Statement Fraud (Studi Pada Perusahaan Sektor Jasa Yang Terdaftar di Bursa Efek Indonesia Periode 2010 dan 2015). Proceeding of Manajemen. Vol 4 No. 3 Page 2722

Ayman, M.Z. 2017. Enron of Saudi Arabia: Corporate Accounting and Auditing Failures. Open Journal of Accounting. Volume 7 Page $1-18$

Cresswell, J.W. 2007. Qualitative Inquiry and Research Design: Choosing Among Five Approaches. Sage Publication: USA

Fabio, G. and Giorgia, M. 2012. Is There a Specific Accrual Basis Standard for the Public Sector? Theoretical Analysis and Harmonization of Italian Government Accounting. Open Journal of Accounting, Volume 1 page 27-37

Http://nasional.tempo.co/read/news/2012/12/04 /173445777/Rp-200-Miliar-DanaPNPM-Dikorupsi. Diakses pada tanggal 17 Juli 2017
Kementerian Pekerjaan Umum, 2012. Informasi Kit Program Nasional Pemberdayaan Masyarakat (PNPM) Mandiri

Krishna G., and Paul, M. 2003. The Fall of Enron. Journal of Economics Perspectives, Volume 17 Page 03-38

Levitt, A. 1998. The Numbers Game. Speech in NYU Center For Law and Business: New York

Moses, D. 1997. Income Smootingand Incentives: Empirical Using Accounting Changes. The Accounting Review. Vol. LXII No.2 Page 259-377

Mulford C., and Comiskey, E. 2002. The Financial Numbers Game : Detecting Creative Accounting Practices. John Wiley \& Sons Inc: New York

Nindya, C. 2016. Faktor-faktor Yang Mempenaruhi Indikasi Kecurangan Dalam Pelaporan Keuangan Dengan Model Fraud Diamond (Studi Empiris Pada Perusahaan Manufaktur Yang Terdaftar Di Bursa Efek Indonesia Periode 2013-2015. Jurnal Publikasi UMY. Universitas Muhammadiyah: Yogyakarta

PSAK No. 1. 2014. Tentang Penyajian Pelaporan Keuangan. Ikatan Akuntan Indonesia; Jakarta

Onojah A., and Unegbu, A. 2013. Review of Accounting Gimmicks Called Depreciation. Open Journal of Accounting, Volume 2 Page 39-44

Schilit, H. 2002. Financial Shenanigans. Second Edition. The McGraw Hill: New York

Schilit, H. 2010. Financial Shenanigans. Third Edition. The McGraw Hill: New York

Skousen, C., Smith, R. and Wright, C. 2009. Detecting and Predecting Financial Statement Fraud: The Effectiveness of The Fraud Triangle and SAS No. 99. Corporate Governance and Firm Performance Advances in Financial Economis, Vol. 13 Page 53-81

Sugiyono. 2009. Metode Penelitian Bisnis : Pendekatan Kuantitatif, Kualitatif, dan $R \& D$. Alfabeta: Bandung 
Summers, S., and Sweeney, J. 1998.

Fraudulently Misstated Financial Statements and Insider Trading: An Empirical Analysis. The Accounting Review. Volume 73 No. 1.

Syed Z., Safdar B., and Yasir, T. 2011. Use or Abuse of Creative Accounting Techniques. International Journal of Trade, Economics and Finance, Vol. 2 page 531-536

Tiffani, L., and Marfuah. 2015. Deteksi Financial Statement Fraud dengan Analisis Fraud Triangle pada Perusahaan Manufaktur yang Terdaftar di Bursa Efek Indonesia. JAAI Volume 19 No.2

Tingkang, Liu. 2017. Cashlet Theory: Discovering the Nature of Accounting. Open Journal of Accounting Volume 6 Page 11-32

Triyuwono, I. 2006. Perspektif, Metodologi dan Teori Akuntansi Syariah. PT. Raja Grafindo Persada: Jakarta

Wells, J. 2005. Principles of Fraud Examination. Hoboken, N.J.: John Wiley \& Sons Inc.

Zuca M., and Ionas C. 2012. Embellishment Of Financial Statements Through Creative Accounting Policies and Options. Procedia-Social and Behavioral Sciences Volume 62 Page 347-351 